\title{
Adolescent Reproductive Health Education Through Training and Counseling on Prevention of Free Relationships, LGBT and HIV AIDS at SMKN 3 Payakumbuh
}

\author{
Skunda Diliarosta ${ }^{\# 1}$, Biomechy Oktomalioputri ${ }^{\# 2}$, Dewi Indriani ${ }^{\# 2}$, Rehani Ramadhani ${ }^{\# 2}$ \\ 1 Universitas Negeri Padang, Jl. Prof. Dr. Hamka Air Tawar Barat, Padang, 40154, Indonesia \\ * Correspondence: skunda@fmipa@unp.ac.id
}

1 November 2019, Disetujui 21 Maret 2020, Dipublikasikan 31 Maret 2020

\begin{abstract}
The purpose of this community service is to educate students in SMKN 3 Payakumbuh How to recognize and maintain reproductive health to avoid free sex, LGBT and HIV/AIDS. The education is well packed and interesting using animated films, discussing and solving problems as well as finding joint solution through a focus group discussion (FGD). This method is done so that students can easily understand about reproductive health and can find out the consequences of free and LGBT associations and HIV/AIDS disease. For initial analysis, this activity using Kahoot application with 75 questions. This activity is done with 5 stages, which is initiated by looking at the knowledge of students, introduce the reproduction tool, Issues of LGBT and Free Sex. Recognizing HIV/AID disease and sufferer data in West Sumatera. Then conducted group discussions with problem tree methods, Focused Group discussion (FGD), discussion of plenary and briefing from the resource person related to knowledge and action of reproductive health, free sex and LGBT. This activity has change attitude of SMKN3 PAYAKUMBUH students with a determination to reject the association/sex free and LGBT through the jargon "Say No to LGBT and Free Sex", in addition to the students are able to fortify themselves from behavior, LGBT and HIV/AIDS. Because adolescent are the next generation of the nation who will fill the richness of Indonesia in the Indonesian Gold ERA in 2045, they are the hope of the nation, the sunlight that will give color to the future of the nation. It is therefore an obligation of all parties to keep them from deviant behavior.
\end{abstract}

Keywords - kesehatan reproduksi, pergaulan bebas, lgbt, hiv aids

\section{Pendahuluan}

Perilaku lesbian, gay biseksual transgender (LGBT) khususnya hubungan seksual antara sesama laki-laki menjadi pemicu HIV tertinggi di Sumatera Barat, sementara data yang dihimpun dari Kementerian Kesehatan terdapat 10.376 kasus HIV pada periode Januari sampai Maret 2018 dan data persentase lelaki suka lelaki sebesar 28 persen.

Penderita AIDS tertinggi berada pada rentang usia 20 sampai 29 tahun sebanyak 29,3 persen. Artinya yang terinfeksi HIV adalah mereka yang melakukan perbuatan berisiko 10 tahun sebelumnya atau pada usia 10 hingga 19 tahun. Diperkirakan saat ini jumlah lelaki penyuka sesama jenis di Sumbar 14.469 orang dan jumlah waria 2.501 orang dengan perkiraan pelanggan 2,5 kali lipat. Artinya kalau pelanggan waria adalah bapak-bapak maka masuk kategori lakilaki suka laki-laki dengan demikian total pria penyuka sesama jenis diperkirakan mencapai 20 ribu orang. Pada tahun 2016 jumlah lelaki penyuka sesama jenis di Sumbar yang menempati posisi paling tinggi di Padang yaitu sebanyak 5.267 orang, Kabupaten Limapuluh Kota dan Payakumbuh sebanyak 1.061 orang, Kabupaten Agam 903, Kabupaten Pesisir Selatan 882, Kabupaten Pasaman Barat 870 orang, Kabupaten 
Padang Pariaman 705 orang, Kabupaten Solok 716 orang. Kabupaten Sijunjung 459 orang, Kabupaten Tanah Datar 434 orang, Kota Pariaman 536 orang, Kabupaten Solok Selatan 339 orang, Kabupaten Dharmasraya 518 orang, Kota Solok 360 orang, Sawahlunto 153 orang, Kota Padang Panjang 135 orang, Kota Bukittinggi 185 orang, dan Kota Pariaman 217 orang.

Salah satu penyebab pemicu fenomena ini adalah karena terjadi krisis karakter di keluarga, sekolah dan masyarakat. Sehingga banyak anak anak mengalami kekerasan waktu kecil, anak kehilangan figur ayah dan lainnya," Masalah ini sering disembunyikan karena dianggap tabu untuk dibicarakan.

Berdasarkan Badan Statistik Amerika Serikat, jumlah penduduk dunia pada Januari 2018 mencapai 7,53 miliar jiwa. Dari jumlah tersebut sekitar seperenam dari penduduk dunia adalah remaja, yakni mencapai 1,22 miliar jiwa. Sedangkan di Indonesia, menurut proyeksi Badan Pusat Statistik (BPS), jumlah penduduk Indonesia tahun 2018 adalah sebanyak 265 juta jiwa lebih. Dari jumlah tersebut sekitar 45 juta jiwa merupakan remaja.

Masa remaja merupakan masa peralihan dari masa kanak-kanak menuju masa dewasa, yang dimulai pada saat terjadinya kematangan seksual. Remaja tidak memiliki tempat yang jelas, bahwa mereka tidak termasuk golongan anak-anak dan juga tidak termasuk golongan dewasa. Perkembangan biologis dan psikologis remaja dipengaruhi oleh perkembangan lingkungan serta perkembangan sosial dari daerah sekitarnya, oleh karena itu mereka akan berjuang untuk melepaskan ketergantungan kepada orang tua dan berusaha untuk mencapai kemandirian supaya mereka dapat diterima dan diakui sebagai orang dewasa.

Masa remaja termasuk masa yang sangat menentukan karena pada masa ini anak-anak mengalami banyak perubahan pada psikis dan fisiknya. Terjadinya perubahan kejiwaan menimbulkan kebingungan dikalangan remaja, mereka mengalami penuh gejolak emosi dan tekanan jiwa sehingga menyimpang dari aturan dan norma-norma social yang berlaku dikalangan masyarakat. Menurut hukum di Amerika serikat, individu dianggap telah dewasa apabila telah mencapai usia delapan belas tahun, bukan dua puluh satu tahun seperti sebelumnya ${ }^{[1]}$. Perpanjangan masa remaja, setelah individu matang secara seksual dan sebelumnya diberi hak serta tanggung jawab orang dewasa mengakibatkan kesenjangan antara apa yang secara popular dianggap budaya remaja dan budaya dewasa. Budaya kawula muda menekan kesegaran dan kelengahan terhadap tanggung jawab dewasa. Budaya ini memiliki hirarki sosial sendiri, keyakinan sendiri, gaya penampilan sendiri, nilai-nilai dan norma perilaku sendiri.

Secara tradisional masa remaja dianggap sebagai periode badai dan tekanan, suatu masa dimana ketegangan emosi meninggi sebagai akibat dari perubahan fisik dan kelenjar. Pertumbuhan pada tahun-tahun awal masa puber terus berlangsung tetapi berjalan agak lambat. Pertumbuhan yang terjadi terutama bersifat melengkapi pola yang sudah terbentuk pada masa puber. Oleh karena itu, perlu dicari keterangan lain yang menjelaskan ketegangan emosi yang sangat khas pada usia ini. Sikap, perasaan atau emosi seseorang telah ada dan berkembang semenjak ia bergaul dengan lingkungannya. Timbulnya sikap, perasaan atau emosi itu (positif atau negative) merupakan produk pengamatan dari pengalaman individu secara unik dengan benda-benda fisik lingkungannya, dengan orang tua, saudara-saudara, serta pergaulan social yang lebih luas. Sebagai suatu produk dari lingkungan (lingkungan internal dan eksternal) yang juga berkembang, maka sudah tentu sikap, perasaan/emosi itu juga berkembang.

Bentuk-bentuk emosi yang sering Nampak dalam masa remaja awal antara lain adalah marah, malu, takut, cemas, cemburu, iri-hati, sedih, gembira, kasih sayang dan ingin tahu. Dalam hal emosi yang negative, umumnya remaja belum dapat mengontrol dengan baik. Sebagai remaja dalam bertingkah laku sangat dipengaruhi oleh emosinya ${ }^{[1]}$. Cara-cara yang dapat ditempuh dalam usaha menemukan dan 
membongkar kekuatan emosi yang terpendam ini dapat dilakukan dengan cara bermain, bekerja dan lebih baik lagi adalah dengan mengatakan kepada seseorang yang dapat menunjukkan gambaran masalah-masalah yang dihadapi remaja yang bersangkutan. Peranan pendidik, guru terutama konselor sangat penting dalam hal ini, sebab mereka dapat melakukannya dengan penerimaan dan pemahaman dalam membantu masalah emosi remaja ini.

Percepatan perkembangan dalam masa remaja yang berhubungan dengan pemasakan seksualitas, juga mengakibatkan suatu perubahan dalam perkembangan sosial remaja. Sebelum masa remaja sudah ada saling hubungan yang lebih erat antara anak-anak sebaya. Sering juga timbul kelompok-kelompok anak, perkumpulanperkumpulan untuk bermain bersama atau membuat rencana bersama, misalnya untuk kemah, atau saling tukar pengalaman, merencanakan aktivitas bersama misalnya aktivitas terhadap suatu kelompok lain. Aktivitas tersebut juga dapat bersifat agresif, kadangkadang kriminal seperti mencuri, penganiayaan, tawuran hingga pergaulan bebas.

Memasuki masa remaja, maka mereka akan dihadapkan pada keadaan yang memerlukan penyesuaian untuk dapat menerima perubahanperubahan yang terjadi. Kematangan seksual dan terjadinya perubahan bentuk tubuh sangat berpengaruh pada kehidupan kejiwaan remaja. Salah satu kehidupan yang sangat menonjol adalah terjadinya peningkatan minat dan motivasi terhadap seksualitas. Dorongan seksualitas remaja itu sangat tinggi dibandingkan dengan dorongan seksualitas orang dewasa. Untuk melepaskan diri dari dorongan seksualitas tersebut, remaja berusaha mengekspresikan dorongan seksualnya dengan berbagai bentuk tingkah laku seksual, mulai dari melaksanakan aktivitas berpacaran, berkencan, dll. Meskipun seksualitas merupakan bagian normal dari perkembangan tapi perilaku seksual tersebut disertai resiko-resiko yang tidak hanya ditanggung oleh remaja saja tetapi juga oleh orang tua ${ }^{[2]}$.
Pada masa remaja terjadi peningkatan minat pada seks, remaja selalu berusaha mencari banyak informasi mengenai seks. Mereka memperoleh pengetahuan tentang seks lewat orang tua, di sekolah, teman-teman, buku-buku, internet, dll. Perempuan sangat ingin tahu tentang keluarga berencana, pil antihamil, pengguguran dan kehamilan. Sedangkan laki-laki ingin mengetahui tentang penyakit kelamin, kenikmatan seks, hubungan seks, dan keluarga berencana.

Usia remaja merupakan usia dimana mereka sedang mencari identitas yang sesuai dengan dirinya. Hal ini mengakibatkan para remaja rawan terpengaruh oleh pihak-pihak luar yang dapat memicu terjadinya bentuk permasalahan sosial pada generasi milineal, yaitu kenakalan remaja. Padahal remaja merupakan generasi bangsa yang semestinya tumbuh dan berkembang ke arah yang positif demi mewujudkan keberlangsungan bangsa, dimana masa yang sulit untuk diterka baik secara kemampuan moralitas, komperensi sosial serta identitas konsep dirinya. Tak jarang para remaja melakukan hal-hal yang dianggap tidak wajar. Seperti pergaulan bebas, perkelahian, kekerasan, melawan, merokok, hingga terjerumus kepada perbuatan terlarang seperti narkoba dan LGBT.

Faktor penyebab terjadinya peningkatan kasus dan angka kenakalan remaja antara lain ialah ratarata remaja yang melakukan kenakalan remaja dilahirkan dan dibentuk dalam situasi keluarga yang kurang berfungsi dan harmonis (disharmonis) sehingga remaja cenderung mencari kepuasan dan sulit mengendalikan diri. Pola interaksi antara guru dan murid telah berubah, hal itu dikarenakan informasi ada dimana-mana, bukan hanya dari guru. Jadi pergeseran perilaku anak bukan hanya dari 'game' atau 'televisi', tetapi karena pola interaksi dunia yang berubah. Guru bukan lagi satusatunya sumber informasi. Itu yang menyebabkan anak-anak sekarang berbeda dengan anak-anak zaman dulu. Selama ini anak tumbuh berdasarkan pemahaman nilai moral dan perilaku sosial dari apa yang dipelajari dari lingkungan, misalnya dengan mendisiplinkan dengan ancaman. 
Berdasarkan data komisi penanggulangan AIDS Nasional (KPAN) tahun 2016, di Sumbar terdapat 15.105 orang LGBT (Lesbian, Gay, Biseksual dan Transgender). Dari angka itu sebanyak 14.252 LSL ( Lelaki Suka Lelaki) dan 853 Waria. Pada tahun 2018 ini , terdapat sekitar 20 ribu orang LGBT di Sumbar ini. Menurut data Perhimpunan Konselor VCT HIV Indonesia (PKVHI) Sumbar mengungkapkan, estimasi pada tahun 2018 terdapat 14.469 orang terdata sebagai Lelaki Suka Lelaki ( LSL), sedangkan jumlah waria 2.501 orang, dan yang lebih parahnya, pelanggan waria mencapai 9.024 orang yang pasti adalah laki-laki.

Pemberian pendidikan kesehatan tentang HIV/AIDS pada pelajar ini sangat penting, karena dengan pendidikan kesehatan kepada pelajar ini dapat menambah pengetahuan, merubah sikap dan menerapkannya dalam kehidupan sehari hari sehingga tercapainya tujuan dari pendidikan kesehatan yaitu meningkatkan derajad kesehatan (kesejahteraan), menurunkan ketergantungan dan memberikan kesempatan pada individu, keluarga, kelompok dan komunitas untuk mengaktualisasi dirinya dalam mempertahankan keadaan sehat yang optimal ${ }^{[3]}$.

\section{Solusi/Teknologi}

Kegiatan Edukasi Kesehatan Reproduksi Remaja melalui Pencegahan LGBT dan Pergaulan bebas dilakukan di SMKN3 Payakumbuh terhadap 30 orang utusan dari masing masing kelas. Proses pelaksanaan kegiatan dilakukan dengan serangkaian kegiatan yang diawali dengan melihat karakteristik siswa SMKN 3 Payakumbuh, memberikan materi materi penyuluhan sebagai pembekalan dalam memahami pentingnya mengenali/menjaga organ reproduksi untuk antisipasi menangkal pergaulan bebas, LGBT dan HIV AIDS. Berikut kegiatan yang sudah dilakukan oleh tim pengabdian masyarakat di SMKN 3 Payakumbuh

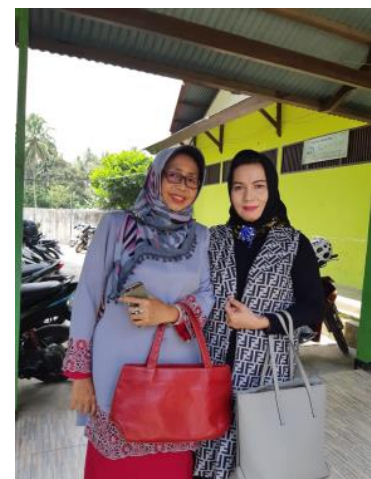

Gambar 1 : Survey awal di SMKN 3 Payakumbuh

Observasi dan survey dilakukan ke sekolah sekolah terutama kesekolah kejuruan yang banyak berhubungan dengan dunia luar baik didalam maupun diluar negeri dalam praktek maupun dunia kerjanya. Peda guru dan tokoh masyarakat kota Payakumbuh. kegiatan ini tim pengabdi melakukan wawancara dengan siswa sekolah dan kepala sekolah beserta guru. Hasil wawancara tersebut diketahui bahwa permasalahan Issu pergaulan bebas, LGBT dan HIV AIDS masih sangat tabu untuk dibicarakan oleh orang tua, guru guru disekolah sehingga siswa mempunyai pemahaman yang berbeda beda dan umumnya mereka mendapatkan informasi dari sumber sumber yang salah dan menjerumuskan serta tidak bisa dipertanggungjawabkan.

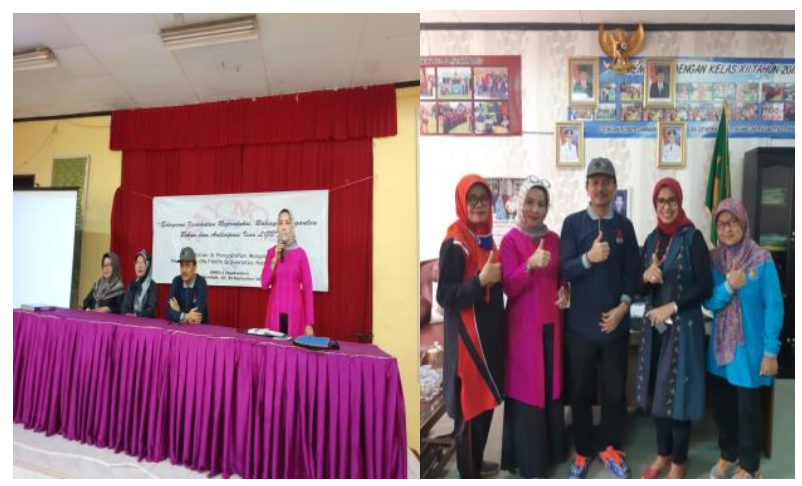

Gambar 2

Acara pembukaan bersama Kepala SMKN 3

Mengukur pemahaman siswa tentang pentingnya mengetahui dan memelihara organ reproduksi dilakukan dengan mengadakan game kuis menggunakan aplikasi Kahoot. Pada kuis ini diberikan pertanyaan singkat mengenai perilaku seksual beresiko dari pergaulan sehari-hari 
remaja. Pada pelaksanaan kuis Kahoot, diperoleh hasil bahwa masih banyak anak SMKN 3 Payakumbuh yang masih kurang memahami bagaiamana menjaga kesehatan reproduksi.

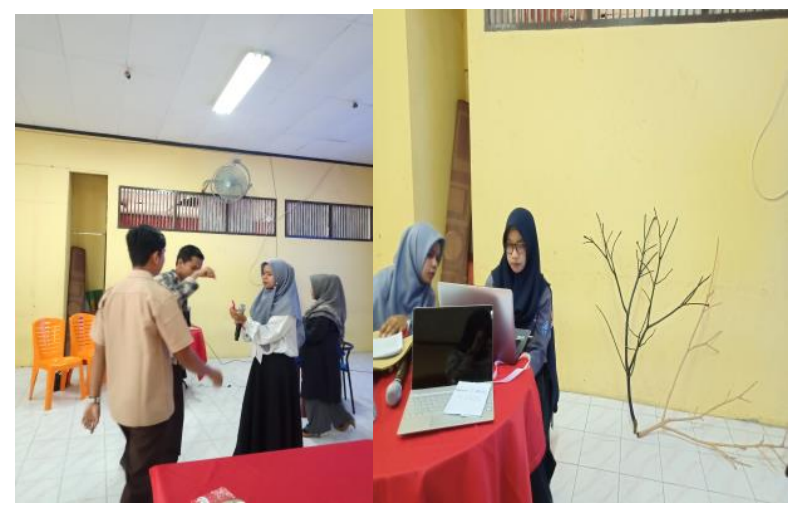

Tim pengabdi memberikan motivasi untuk dapat mengenali dan menjaga setiap organ reproduksi. Tim pengabdi juga menjelaskan melalui pemaparan materi mengenai pengetahuan kesehatan reproduksi oleh Dr. Skunda Diliarosta, M.Pd. pemberian materi mengenai kesehatan reproduksi, bahaya pergaulan bebas dan LGBT. Pemaparan materi disampaikan oleh narasumber kedua yaitu Sofita Yenuris, S.H.M.H, dilanjutkan pemaparan meteri HIV/AIDS. Materi disampaikan oleh Yoshelda, S.Keb. M, Kes.. Pada penyampaian materi ini dibahas bagaimana penyebab dari penyakit HIV/AIDS dan perilaku yang dapat menyebabkan penyebaran dari HIV/AIDS serta cara pencegahannya.

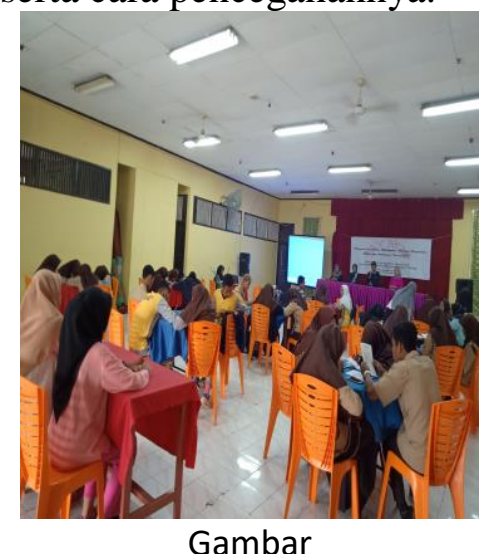

Peserta Pelatihan

Mahasiswa diberikan kasus yang didiskusika dalam kelompok dan dipecahkan melalui pohon masalah. Kepada peserta pelatihan peserta diberikan modul dalam upaya mengenali dan menjaga reproduksi remaja agar terhindar dari dampak yang akanmerusak masa depan.

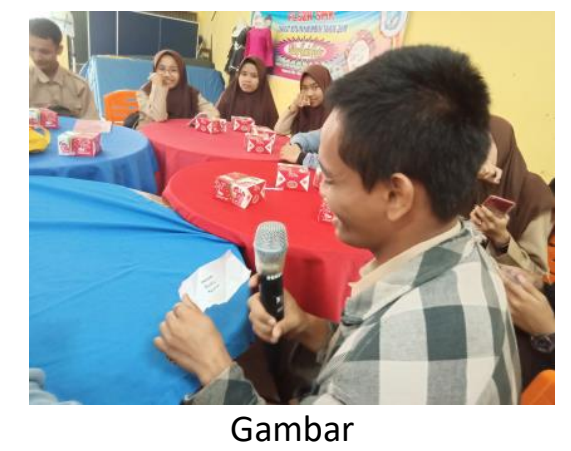

Suasana diskusi yang menyenangkan

Solusi yang bisa diterapkan untuk pencegahan LGBT pada remaja yang ada di sekolah, bisa dilakukan dengan beberapa upaya. Antara lain, monitoring pergaulan. Era sekarang, remaja terbuka terhadap pergaulan dan media sosial yang menyediakan informasi sehingga bisa terpengaruh terhadap nilai-nilai yang bertentangan dengan norma agama dan sosial. Maka, perlu orangtua dan guru memonitor pergaulan anak anak remaja, memastikan aktivitas mahasiswa positif dan pemakaian media sosial yang sehat. Melakukan penelitian terkait bahaya dan penanggulangan LGBT di perguruan tinggi sehingga solusi itu cocok untuk mencegah berkembangnya LGBT di sekolah. Terapi (pengobatan) Sebagian pakar sepakat bahwa LGBT adalah penyimpangan perilaku seksual sehingga perlu diobati melibatkan para pakar dan kesadaran dari orang yang telanjur LGBT itu sendiri. Terapi bisa berbentuk kognitif dan behavior.

Menurut Prof Malik Badri, pendiri
International Association of $\begin{array}{r}\text { Muslim } \\ \text { Psychologists, terapi kognitif }\end{array}$ untuk
membangunkan kesadaran bahwa yang
dilakukannya salah, tanpa menyudutkan. Selain
itu terapi menumbuhkan motivasi kepada
seseorang. Kemudian, terapi behavior dengan
memasukan seseorang ke dalam lingkungan yang
lebih "bersih dan baik" guna membentuk ulang
perilakunya.

Sekolah harus menyediakan pakar yang bisa memberikan edukasi menghindari LGBT ini. Sebagian pakar mengatakan bahwa LGBT penyakit menular, maka perlu ketegasan regulasi 
untuk mencegah penularannya, baik dari sisi pemerintah daerah maupun institusi kesehatan di negeri ini. Semua agama sepakat bahwa LGBT itu adalah dosa. Maka, orang-orang yang sudah atau berpotensi LGBT perlu diberikan pencerahan agama dari masing- masing pakar agama yang diyakininya. Sekolah sebaiknya menyediakan tausyiah-tausyiah pencegahan LGBT di kampus.

Peningkatan keimanan dan ketakwaan kepada Tuhan YME, penyaluran minat dan bakat secara positif merupakan hal-hal yang dapat membuat setiap orang mampu mencapai kesuksesan hidup nantinya. Tetapi walaupun kata-kata tersebut sering 'didengungkan' tetap saja masih banyak remaja yang melakukan hal-hal yang tidak sepatutnya dilakukan. Berusaha untuk memperbaiki cara pandang dengan mencoba bersikap optimis dan hidup dalam "kenyataan", maksudnya sebaiknya remaja dididik dari kecil agar tidak memiliki angan-angan yang tidak sesuai dengan kemampuannya sehingga apabila remaja mendapatkan kekecewaan mereka akan mampu menanggapinya dengan positif.

Remaja harus belajar disiplin dengan mengelola waktu, emosi, energi serta pikiran dengan baik dan bermanfaat, misalnya mengatur waktu dalam kegiatan sehari-hari serta mengisi waktu luang dengan kegiatan positif. Menyadari pada dasarnya tiap-tiap individu ingin yang terbaik untuk diri masing-masing. Sehingga pergaulan bebas tersebut dapat dihindari. Jadi dengan ini remaja tidak menganiaya emosi dan diri mereka sendiri.

Memperbaiki cara berkomunikasi dengan orang lain perlu ditingkatkan sehingga terbina hubungan baik dengan masyarakat, untuk memberikan batas diri terhadap kegiatan yang berdampak negatif dapat kita mulai dengan komunikasi yang baik dengan orang-orang di sekeliling kita.

Remaja perlu berpikir untuk masa depan, tidak jarang remaja sekarang jarangnya memikirkan masa depan. Seandainya tiap remaja mampu menanamkan pertanyaan "Apa yang akan terjadi pada diri saya nanti jika saya lalai dalam menyusun langkah untuk menjadi individu yang lebih baik?" kemudian hal itu diiringi dengan tindakan-tindakan positif untuk kemajuan diri para remaja. Dengan itu maka remaja-remaja akan berpikir panjang untuk melakukan hal-hal menyimpang dan akan berkurangnya jumlah remaja yang terkena HIV \& AIDS nantinya.

Kalangan remaja kita kebanyakan sudah tak mengindahkan lagi akan pentingnya nilai-nilai ketimuran. Tentu saja nilai ketimuran ini selalu berkaitan dengan nilai Keislaman yang juga membentuk akar budaya ketimuran. Nilai yang bersumberkan pada ajaran spiritualitas agama ini perlu dipegang. Termasuk meningkatkan derajat keimanan dan moralitas pemeluknya. Dengan dipegangnya nilai-nilai ini, harapannya mereka khususnya kalangan muda akan berpikir seribu kali untuk terjun ke pergaulan bebas.

Dikalangan muda, pergaulan bebas sering dilakukan karena bisa jadi mereka tidak tahu akibat yang ditimbulkannya. Seperti misalnya penyakit kelamin yang mematikan. Nah, sosialisasi hal ini. Informasi-informasi mengenai bahaya yang ditimbulkan akibat pergaulan bebas ini perlu terus disebarkan di kalangan muda. Harapannya, mereka juga punya informasi sebagai bahan pertimbangan akal sehatnya. Jika informasi tersebut belum didapatkan ada kemungkinan mereka akan terus melakukan pergaulan bebas semau mereka. Tapi, kalau informasi sudah didapatkan tapi mereka tetap nekad melakukan itu persoalan lain lagi. Sepertinya perlu ada penanganan khusus, apalagi yang sudah terang-terangan bangga melakukan pergaulan bebas.

Dalam menghadapi masalah pergaulan bebas antar jenis di masa kini, orangtua hendaknya memberikan bimbingan pendidikan seksual secara terbuka, sabar, dan bijaksana kepada para remaja. Remaja hendaknya diberi pengarahan tentang kematangan seksual serta segala akibat baik dan buruk dari adanya kematangan seksual. Orangtua hendaknya memberikan teladan dalam menekankan bimbingan serta pelaksanaan latihan kemoralan. Dengan memiliki latihan kemoralan 
yang kuat, remaja akan lebih mudah menentukan sikap dalam bergaul. Mereka akan mempunyai pedoman yang jelas tentang perbuatan yang boleh dilakukan dan perbuatan yang tidak boleh dikerjakan. Dengan demikian, mereka akan menghindari perbuatan yang tidak boleh dilakukan dan melaksanakan perbuatan yang harus dilakukan.

Apa yang dapat kita lakukan di SMK N 3 Payakumbuh agar remaja/siswa siswi tidak terjerumus pada pergaulan bebas, LGBT dan kesadaran menjaga kesehatan reproduksi agar masa depan bisa cerah.

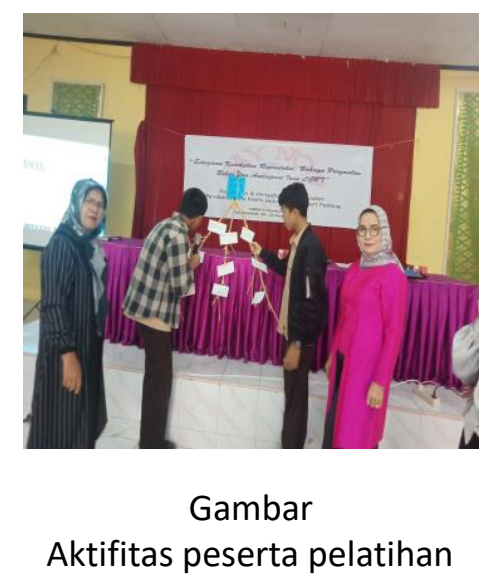

Salah satu solusi yang dapat dilakukan untuk mengatasi masalah di atas yaitu dengan memberikan edukasi kepada siswa/i SMK N 3 Payakumbuh tentang bagaimana cara menjaga kesehatan reproduksi remaja dan memperlihatkan bagaimana akibat atau resiko pergaulan bebas dan LGBT. Pengetahuan adalah hasil tahu dari manusia dan ini terjadi setelah orang melakukan penginderaan terhadap suatu obyek tertentu ${ }^{[4]}$.

Pengetahuan tentang pengenalan alat reproduksi dan kesehatan reproduksi pada remaja sangatlah kurang. dikarenakan kurangnya informasi yang diperoleh dengan benar tentang kesehatan reproduksi, masyarakat masih menggap tabu untuk dibicarakan, para orang tua dan guru tidak mampu menyampaikan informasi ini secara lugas. Penerapan tentang pengetahuan kesehatan reproduksi yang baik akan menjadi dasar terbentuknya perilaku seksual yang sehat ${ }^{[5]}$. Faktor-faktor yang Mempengaruhi Pengetahuan
Menurut Wawan A. (2010), faktor-faktor yang mempengaruhi pengetahuan secara umun terdapat 2 faktor yaitu Faktor Internal yaitu Pendidikan , Pekerjaan ,Umur, Pengalaman dan Faktor Eksternal yaitu Faktor Lingkungan, Sosial Budaya.

Dampak negatif dari perilaku pergaulan bebas dan LGBT sudah sedemikian banyak oleh karena itu, diperlukan suatu cara penanggulangan untuk menghindari pergaulan bebas. Lebih mengenal bahaya dan dampak pergaulan bebas, seperti penyakit menular seksual dan sebagainya. Salah satu cara mengatasi permasalahan ini adalah dengan memberikan motivasi kepada siswa/i SMK N 3 Payakumbuh agar menjadi remaja yang sadar akan kesehatan reproduksi khususnya pergaulan bebas dan LGBT serta merencanakan pembuatan sarana edukasi kesehatan reproduksi, resiko pergaulan bebas dan LGBT.

\section{Hasil dan Diskusi}

Hasil dari kegiatan Edukasi Reproduksi sebagai antisipasi pergaulan bebas, LGBT dan HIV AIDS ini menunjukkan adanya peningkatan pengetahuan, pemahaman dan meningkatkan semangat siswa dalam menjaga organ reproduksi agar terhindar dari pergaulan bebas, LGBT dan HIV AIDS. Hal ini terbukti dengan adanya perubahan cara pandang, sikap siswa terhadap permasalah organ reproduksi, akibat pergaulan bebas, LGBT dan HIV AIDS menjadi lebih baik. Pesrta dapat dengan lantang melontarkan jargon

"Say No to LGBT and Free Sex". Diharapakan dengan pengabdian ini siswa SMKN 3 Payakumbuh mampu menjaga dan memelihara reproduksi menghindari diri dari pergaulan bebas dan LGBT dan HIV AIDS. Dengan demikian Edukasi Kesehatan Reproduksi berbasis game Website dapat meningkatkan pengetahuan dan pemahaman siswa sehingga mampu menolak pergaulan bebas dan LGBT serta terhindar dari HIV AIDS

\section{Kesimpulan}

Dengan adanya kegiatan pengabdian ini, 30 orang siswa yang mengikuti kegiatan pengabdian telah menjadi pribadi yang 
memahami tentang pentingnya menjaga kesehatan reproduksi terhindar dari pergauan bebas, LGBT dan HIVAIDS. Dan diharapkan siswa yang menjadi peserta di acara pengabdian dapat mengajak teman-teman disekitarnya menjadi pribadi yang juga memahami pentingnya menjaga kesehatan reproduksi dengan menghindari perilaku pergaulan bebas dan LGBT dan terhindar dari HIV/AIDS. Metode edukasi dengan model berbasis website ini sangat efektif dilakukan pada remaja.

\section{Ucapan Terima Kasih}

Ucapan terima kasih diberikan kepada seluruh kolega yang telah mendukung keberlangsungan kegiatan serta mitra kami SMKN 3 Payakumbuh.

\section{Pustaka (12pt)}

[1] Hurlock, E. B. (2002). Psikologi Perkembangan Suatu Pendekatan Sepanjang Rentang Kehidupan, Cet.5. Jakarta: Erlangga.

[2] Desmita. (2013). Psikologi Perkembangan, Cet.8. Bandung: PT. Remaja Rosdakarya.

[3] Harmawati, Desriza Artika Sari, Devi Verini. 2018. Pengaruh Pendiidikan Kesehatan Terhadap Tingkat Pengetahuan Pelajar SMA Tentang HIV/AIDS. Jurnal Endurance

[4] Gnotoadmojo, S. 2005. Metodologi Penelitian Kesehatan. Jakarta: Info Medika.

[5] Nurlena Andalia, Agnes, M. Ridhwan. 2017. Hubungan Antara Pengetahuan Dengan Persepsi Siswa Terhadap Penularan Penyakit AIDS. Jurnal 